\title{
Does Athletic Participation Signal Employability?: An Experimental Analysis of Male and Female Athlete Job Applicants
}

\author{
Brendan Dwyer and Jennifer L Gellock \\ Virginia Commonwealth University
}

\begin{abstract}
College athletes face high expectations to compete on the field and in the classroom. However, the time demands associated with athletics and academics often limit their ability to engage in traditional college experiences. Internships or practical job trainings are one such opportunity unfortunately forgone due to the time constraints of the contemporary college athlete experience. This results in an issue when applying for jobs outside of sport, as direct internship experience positively impacts an individual's likelihood to be hired into an entry-level position. Through the application of signaling theory, the current study explored the perceived value of intercollegiate athletic participation compared to and in addition to direct internship experience via four résumé evaluation experiments. Two hundred and thirty five individuals with hiring experience participated; results suggested athletic participation was perceived as at least equally favorable to direct internship experience. However, male athletes without direct internship experience were more likely to receive an interview and received higher unobserved attribute ratings than female athletes with the exact same credentials.
\end{abstract}

Keywords: career transition, college athlete development, experimental design, gender equity

There are only $168 \mathrm{hr}$ in a week, and intercollegiate athletes seem to make productive use of every one, or, at least, that is the expectation. Intercollegiate athletics is fiercely competitive, especially at the highest level (Division I), and while coaches and administrators are evaluated on a number of factors, they are primarily hired and fired based on the athletic performance of athletes (Holmes, 2011). Competition, however, is unpredictable. An awkward bounce of the ball, bad weather, or missed call by an official can be the difference between winning and losing. It is difficult to prepare for competitive unpredictability; thus, coaches focus their time and effort on what they can control: pregame preparation. This, however, takes time, and despite the fact it is regulated by the National Collegiate Athletic Association (NCAA), athletes often go beyond the maximum number of

Dwyer and Gellock are with the Center for Sport Leadership, Virginia Commonwealth University, Richmond, VA. Address author correspondence to Brendan Dwyer at bdwyer@vcu.edu. 
contact hours in a given week (NCAA, 2016a). Whether it is on-field practices or games, film study, team meetings, weight training, study hall, or injury rehabilitation, college athlete schedules are overloaded, and that does not include time spent eating, sleeping, and going to class. It certainly does not include a social life.

In addition to these time demands, the increasing financial investment and commercialized nature of Division I athletics have created a climate within athletic departments and on university campuses where athletes are increasingly isolated from nonathletes (Bok, 2003; Southall \& Staurowsky, 2013). Athletes live in their own dorms, eat in their own dining halls, and, depending upon the campus, often do not have to leave a well-defined athletic village unless attending classes. This is by design. On-field success leads to enhanced notoriety and financial returns; thus, universities continue to invest large sums of money into college athletics as means to remain competitive and achieve institutional goals (Southall, Southall, \& Dwyer, 2009). The pressure associated with this investment trickles down to the athletes, who find their choices related to an autonomous college experience limited (Huma \& Staurowsky, 2011).

In other words, college athletes rarely have the opportunity to engage in activities of a traditional college student. From joining student organizations to participating in study abroad programs, athletes often sacrifice the traditional college experience in order to participate in intercollegiate athletics (Coach for College, 2017; Gayles \& Hu, 2009). An argument can be made that the opportunity to participate in Division I intercollegiate athletics is well worth these sacrifices; however, what if this opportunity not only hindered the traditional college experience but also impeded an athlete's career opportunities outside of sport?

It is likely you have seen the 2011 NCAA commercial that concludes with "there are over 400,000 NCAA athletes, and just about all of us will be going pro in something other than sports" (NCAA, 2011). This advertisement showcased the work ethic and commitment required of athletes; thus, it was a public service announcement for the NCAA signaling employers to consider college athletes for their open positions. It was likely an attempt by the NCAA to overcome the lack of direct industry experience possessed by college athletes. Internships and job shadowing experiences are additional traditional college student opportunities that athletes, unfortunately, often pass up or are forced to miss due to the time demands of the Division I intercollegiate athletic experience (Gayles \& Hu, 2009). The research on direct internship experience is quite clear; it is the primary predictor for securing an entry-level position (Nunley, Pugh, Romero, \& Seals, 2016). Thus, athletes who do not gain this experience could be at a disadvantage when competing for employment directly after graduation.

As a means to recoup industry experience, intercollegiate athletic participation is seen as a vehicle for life skills development such as leadership, communication, and determination (Miller \& Kerr, 2002; Paule \& Gilson, 2010). Yet, there is little evidence to suggest that these skills are transferable to one's résumé. Furthermore, there is little research on the extent to which the average hiring professional values Division I intercollegiate athletic participation. Are hiring professionals able to identify life skills attributes on a Division I college athlete's résumé? Furthermore, how do they view Division I intercollegiate athletic participation in comparison to direct internship experience? The answers to these questions are vital for current and prospective college athletes as well as intercollegiate coaches, athletic 
administrators, and university professionals, in general. The results of the current study should directly inform career transition programming, such as internship coordination and/or job placement services. Also, given important recent discussions around the gender pay gap and gender equity in hiring practices (Abraham, 2017; Carlsson \& Sinclair, 2018), the current study aims to contribute to what we know about perceptions of male and female Division I college athletes in hiring practices.

As a result of these important issues, the purpose of the current study was threefold. First, this study explored the perceived value of Division I intercollegiate athletic participation compared to and in addition to direct internship experience through four résumé evaluation experiments. Second, differences in the ratings of the unobserved attributes of leadership, interpersonal skills, intelligence, and motivation were examined among college athlete résumés. Third, differences in the ratings between male and female athletes with the exact same résumé were analyzed. Based on previous research and guided by signaling theory, a series of hypotheses were developed and tested through a convergent parallel mixedmethods design. The following broad research questions were developed to guide this study:

RQ1: In a résumé evaluation scenario, how does Division I varsity intercollegiate athletic experience equate to direct internship experience?

RQ2: In a résumé evaluation scenario, to what extent are there differences in hiring professionals' ratings of the unobserved attributes of a Division I college athlete résumé?

RQ3: In a résumé evaluation scenario, are female Division I athletes rated differently than male athletes?

\section{Literature Review}

\section{Theoretical Framework: Signaling Theory}

Signaling theory proposes that employers observe an abundance of personal data on job applicants gathered primarily from résumés (Harvey-Cook \& Taffler, 2010). The observed biodata "signals" job recruiters to unobservable characteristics and attributes that an individual possesses (Spence, 1973). Examples of unobservable characteristics signaled from résumés are intelligence, interpersonal skills, leadership, and motivation (Wilkin \& Connelly, 2012). Education, work experience, and extracurricular activities are all examples of traditional résumé categories that signal unobservable attributes which are used to make inferences about an individual's character, especially for entry-level positions (Briggeman \& Norwood, 2011). Based off inferences gathered from résumés, assumptions can also be made about the future success of a potential new employee (Nemanick \& Clark, 2002). Since the goal of a job recruiter is to hire the best possible candidate, inferences drawn from résumés become crucial in finding the individual who is the best fit.

Signaling theory has been used in numerous business and management studies to explain how unobservable characteristics can signal employers to the quality 
of one's human capital (Connelly, Certo, Ireland, \& Reutzel, 2011; Maurath, Wright, Wittorp, \& Hardtke, 2015; Wilkin \& Connelly, 2012). Human capital can best be explained by the experiences an individual has had, that future employers value (Briggeman \& Norwood, 2011; Lavalle, 2010). For example, Maurath et al. (2015) applied signaling theory to investigate how volunteer experience on résumés aid individuals who have gaps in their employment history and also lack recent work experiences. In a similar study, Wilkin and Connelly (2012) explored volunteer experiences as potential signals of unobservable characteristics to job recruiters. The authors' findings suggested that relevant experience, no matter if it is paid (internship or job) or unpaid (volunteer), did not significantly sway a job recruiter's opinion to choose one applicant over another. These results demonstrate that any relevant experience signals positive résumé evaluations. The above examples demonstrate that when individuals participate in certain résumébuilding experiences it can make them stand out amongst the job applicant pool. According to Bangerter and Roulin (2012), standing out to employers is one way applicants can gain a competitive edge to increase one's human capital.

Experiences on a résumé that signal unobservable characteristics are controllable, according to Spence (1973). This means that individuals make choices to partake in certain experiences while forgoing others. For example, college athletes who decide to invest in athletics during their time in college may in turn be prevented from investing in other opportunities such as internships. Given the large number of articles within the management literature that have utilized signaling theory in different organizational contexts, it makes for a valid framework to explore phenomena related to hiring practices (Connelly et al., 2011). As a result, the application of signaling theory to this context provides an established framework to assess the intercollegiate athletic experience in conjunction with the unobservable characteristics of job applicants based on their résumés.

\section{Intercollegiate Athletic Experience}

Compared to their nonathlete peers, athletes partake in a unique college experience (Gayles \& Hu, 2009; Howard-Hamilton \& Watt, 2001). These experiences noted in the literature relate to college athletes' time-demanding schedules, pressure to perform at high academic and athletic levels, and their psychological and sociological adaptations to college (Rubin \& Moses, 2017; Watt \& Moore, 2001). The most recent GOALS survey, reported in 2015 by the NCAA, showed that college athletes at the NCAA Division I level self-reported, on average, spending $34 \mathrm{hr}$ per week committed to sport and $38.5 \mathrm{hr}$ a week committed to academics (NCAA, 2016a). These numbers suggest college athletes dedicate an immense amount of time to their athletic and academic roles, which may explain their nonparticipation in extracurricular activities such as jobs, social activities, and on-campus functions (Gayles \& Hu, 2009).

Due to the above-mentioned time commitments and unique experiences of college athletes, researchers have become interested in examining athlete engagement during their time in college (Pascarella \& Terenzini, 2005; Umbach, Palmer, Kuh, \& Hannah, 2006). College student engagement is the amount of involvement an individual devotes to participating in purposeful educational activities (Astin, 1984). Such involvement can be beneficial for students both inside and outside of 
the classroom. Given the lack of time compared to their nonathlete peers to engage in such activities, it warrants continued investigation if less involvement could impact athletes' future employability.

A qualitative study by Paule and Gilson (2010) examined the benefits and challenges that college athletes face daily. The authors found that some of the challenges college athletes are faced with are a lack of free time and missing out on certain college experiences. These experiences consisted of participating in social events with peers and attending professional opportunities. As a result, the costs and benefits associated with being an athlete contributed to these athletes having to make tough decisions between their academic, athletic, and social commitments. In another qualitative study by Haslerig and Navarro (2015), athletes mentioned the sacrifices made for athletic participation, as it was difficult to excel academically and athletically. In addition and directly related to the current study, the athletes also expressed frustration with the feasibility, or lack thereof, of obtaining industry or direct internship experience (Haslerig \& Navarro, 2015).

Direct internship and job-related experiences on résumés have been found to improve a candidate's employment prospects (Nunley et al., 2016). These out-ofclassroom experiences are important for purposeful engagement and direct application of skills learned in the classroom. These experiences provide undergraduate and graduate students with the opportunity to gain the on-the-job skills needed to be successful in an entry-level position. Internship and practical experiences integrated into course curriculum are often referred to as experiential learning. This type of learning is used to bridge the gap between what students are learning in the classroom and real-life job experiences (Aldas, Crispo, Johnson, \& Price, 2010). In addition to enhanced employability, it has been also found that those with internship experience earn higher job salaries and have increased job satisfaction compared to those without prior internship experience (Gault, Redington, \& Schlager, 2000). For these reasons, some academic majors are adding mandatory internship components of experiential learning into the degree curriculum (Cantor, 1997). However, until every major makes internship experience a requirement for graduation, college athletes may continue to forgo this experience before entering the job market.

Since college athletes may be missing out on certain opportunities, such as internship experiences, it is important to recognize the many direct and indirect benefits associated with competing in intercollegiate athletics. Being an athlete has been found to be positively associated with an individual's overall college experience, motivation to graduate, and the development of interpersonal and leadership skills (Potuto \& O'Hanlon, 2007; Ryan, 1989). Experiences facilitated through sport can assist with the development of personal characteristics and transferable life skills (Papacharisis, Goudas, Danish, \& Theodorakis, 2005). A USA Today article, "Recruiters Want to Hire College Athletes" provided a list of reasons why employers may want to hire college athletes: goal oriented, time management skills, self-confident, interpersonal skills, and leadership (Bastie, 2015). These characteristics athletes possess are skills employers specifically seek (Chalfin, Weight, Osborne, \& Johnson, 2015). Hence, the value gained from participating in intercollegiate athletic experience has the potential to translate into skills and developmental characteristics needed for on-the-job success after graduation. 
If college athletes are missing out on direct internship experiences but are still gaining other potential benefits job employers seek, it is crucial to understand more about how intercollegiate athletic experience signals unobservable characteristics to potential employers. It is known that personal development and life skills are fostered through sport; however, more empirical evidence is needed to investigate how these characteristics and attributes athletes gain through their college sport experience are valued in the workplace. Thus, in a résumé evaluation scenario, is an applicant with only intercollegiate athletic experience rated equally to an applicant with only direct internship experience? The following hypotheses were developed to answer research question one:

H1: As it relates to unobserved attributes, a male applicant with direct internship experience will be rated equal to or higher than a male applicant with intercollegiate athletic experience, but no direct internship experience.

H2: As it relates to receiving an interview, a male applicant with direct internship experience will be recommended equal to or higher than a male applicant with intercollegiate athletic experience, but no direct internship experience.

\section{Qualifications Based on Gender}

Though there has been a rise in the number of women in the workforce and number of women in managerial positions, gender stereotypes in hiring practices still exist (Powell, Butterfield, \& Parent, 2002). Male-dominated professions, such as business, still prefer to hire males to females (Koch, D’Mello, \& Sackett, 2015). One of the reasons researchers ascribe to these findings can be explained by role congruity theory (Eagly \& Karau, 2002). Role congruity theory describes how an individual or group will be positively recognized when his/her characteristics are identified within the assumed stereotype. This may explain why there is bias in hiring women in terms of the congruence between the job requirements and stereotype of the female gender. Studies have also been conducted on faculty's perceptions of their gender and job competency in male-dominated majors. Grappendorf and Burton (2016) found evidence that even faculty who teach students may perceive males as a better-fit specifically for male-dominated organizations such as the National Football League (NFL). For this reason, it is plausible to think that female athletes applying for jobs may be viewed differently than male applicants when they go on the job market. As a result, the following hypotheses were determined.

H3: As it relates to unobserved attributes, a male applicant with direct internship experience will be rated equal to or higher than a female applicant with intercollegiate athletic experience, but no direct internship experience.

H4: As it relates to receiving an interview, a male applicant with direct internship experience will be recommended equal to or more than a female applicant with intercollegiate athletic experience, but no direct internship experience. 


\section{Athletics $=$ Value Added?}

There is limited research on the topic that empirically explores the benefits college athletes gain from their experiences that differ from their nonathlete peers. There seems to be some association with competing in sport to life skills needed upon graduation. Potuto and O'Hanlon (2007) found that college athletes self-reported they personally believed that being a college athlete added value to their college experience that their nonathlete peers did not have. A quantitative study by Weight, Navarro, Huffman, and Smith-Ryan (2014) measured specific psychological, physiological, and intellectual constructs and found that college athletes had significantly higher scores on teamwork, leadership, bravery, and perseverance compared to nonathletes. These findings allude to why some companies specifically seek to hire former athletes when recruiting new employees, possibly because of these initial understandings of value of competing in college athletics. Chalfin et al. (2015) studied a sample of companies who recruit athletes through specific athlete recruitment websites (e.g., www.careerathletes.com). The following attributes were found to be characteristics athletes possess that companies value: competitive nature, goal orientation, ability to handle pressure, work ethic, confidence, coachability, ability to work with others, self-motivation, mental toughness, and time management skills. Findings also suggested these characteristics are valued more when comparing a collegiate athlete to a nonathlete who holds leadership positions for campus organizations. Ultimately, these specific companies valued certain unobservable attributes of athletes and view them transferable into the workplace.

Along with companies that seek to hire former college athletes, there are also companies that work to connect interested employers with former athletes. Game Theory Group and Athlete Network are two businesses that work to recruit and connect former athletes with these companies (Chalfin et. al., 2015). The majority of workplaces, however, do not specifically recruit former athletes. The current study has potential to help determine if recruiters are signaled the unobservable attributes positively associated with college athletes. Based on literature and the potential value added from being a college athlete, coupled with practical job experience, the following hypotheses were created to further answer research question one:

H5: As it relates to unobserved attributes, a male applicant with direct internship experience will be rated less than a male applicant with intercollegiate athletic experience and direct internship experience.

H6: As it relates to an interview, a male applicant with direct internship experience will be recommended less than a male applicant with both intercollegiate athletic experience and direct internship experience.

H7: As it relates to unobserved attributes, a male applicant with direct internship experience will be rated less than a female applicant with both intercollegiate athletic experience and direct internship experience.

H8: As it relates to receiving an interview, a male applicant with direct internship will be recommended less than a female applicant with both intercollegiate athletic experience and direct internship experience. 
It is important to note that previous research to support distinct differences between unobserved attributes or certain life skills was not available. Thus, hypotheses for research question two were not created.

\section{Male and Female College Athletes}

During their time in college, female athletes spend more time focusing on their academic roles compared to their male athlete counterparts (Sturm, Feltz, \& Gilson, 2011). Female athletes have been found to be more academically motivated and currently graduate at a higher rate in comparison to male athletes (Gayles, 2005; NCAA, 2016b). One of the reasons for this may be due to the smaller chance for female athletes to have a professional career once their eligibility is exhausted. Regardless, there is still limited literature examining differences in the male and female athlete experience as it relates to career development.

A few studies have examined the quality of potential job candidates based on the gender among college athletes. In their study on examining why companies target former athletes as employees, Chalfin et al. (2015) found no significant findings based on gender. Females and males who played the same sport, at the same level, were rated equally. Tanguay, Camp, Endres, and Torres (2012) found that males and females were rated similarly in overall ratings based on résumé data during an initial job screening.

Outside of sport, there has been extent of literature examining gender bias in hiring practices in the general business management literature. A meta-analysis study by Koch et al. (2015) revealed gender bias may still be a concern in workplace hiring. Examining 22,348 experimental studies, they found that males are preferred for male-dominated jobs. Male raters were also more likely than women to rate males higher for these male-dominated positions. The job opening used for the current study was a business marketing position, which could highlight biases since business is a male-dominated industry. Similarly, Powell et al. (2002) concluded from their longitudinal study, which had three data collections during the years of 1985, 1977, and 1999, that even though more women are being hired in managerial positions during this time, the sample of business students over the years responded that they preferred managers with more masculine characteristics.

However, what does gender hiring and bias look like among different subpopulations, such as college athletes? Taking a similar methodological approach to the current study, Grappendorf, Burton, and Henderson (2008) used mock interview evaluations and found that male athletes did have an advantage over female athletes and male and female nonathletes. Specifically, males were recommended for a greater starting salary, especially when evaluated by male reviewers. However, results from Grappendorf and Burton (2014) contradicted findings from the first study and found that female athletes, when compared to both male athletes and male and female nonathletes, were rated higher and recommended in a résumé evaluation. Given the discrepancy of findings in how female and male athletes are treated in hiring situations, it remained very important for the current study to explore gender differences among athletes. As a result, hypotheses 9 and 10 were developed to answer research question three. 
H9: As it relates to unobserved attributes and a potential interview, a male applicant with intercollegiate athletic experience, but no direct internship experience, will be rated equally to a female applicant with intercollegiate athletic experience, but not direct internship experience.

H10: As it relates to unobserved attributes and a potential interview, a male applicant with both intercollegiate athletic experience and direct internship experience will be rated equally to a female applicant with intercollegiate athletic experience with direct internship experience.

\section{Method}

In order to answer the research questions and test the hypotheses, the current study utilized a convergent parallel mixed-methods design, where quantitative and qualitative data were collected simultaneously, analyzed separately, and then converged for interpretation (Creswell, Plano Clark, Guttmann, \& Hanson, 2003). This design was utilized because it was imperative to understand the decision making of the sample participants in greater detail (Creswell \& Plano Clark, 2011). The approach was primarily quantitative, but the qualitative analysis provided important context to the results.

\section{Participants and Procedure}

Through partnerships with a local newspaper and a local events commission, a sample was solicited from a panel of previous or current newspaper subscribers, event participants, and/or event spectators. The total panel consisted of 1,036 email addresses. Demographic and psychographic information was available for the entire panel, as the population has been utilized for other research initiatives (see Table 1). Given the purpose of the study, working professionals with hiring experience was the target population, and survey procedures were utilized to ensure a representative sample. This panel was specifically selected based on demographics that matched the Bureau of Labor Statistics (BLS, 2017) average estimations for management occupations: age (44), education ( $>50 \%$ bachelors or above), and household income $(\$ 100,000)$. The distribution of self-reported gender for the current population was skewed toward a higher female population than provided by the BLS, but, once again, survey-screening questions were utilized to ensure the most generalizable sample possible.

Potential respondents were solicited via email from the research team; a follow-up email was sent 2 weeks later. In each email, potential respondents were provided a link to an online survey hosted by Qualtrics (Provo, UT/Seattle, WA). In addition, the following information was provided:

You are now being asked to participate in a study of potential employers. The purpose of this confidential survey is to better understand how you rate one's academic and extracurricular experience in the context of hiring. College students are faced with difficult decisions with their time outside of the classroom, and your assessment of their possible opportunities (internships or other extracurricular activities) will help them understand the benefits and 
Table 1 Sample and Population Demographics $(\mathbf{N}=\mathbf{2 3 5})$

\begin{tabular}{|c|c|c|}
\hline & Sample & Panel \\
\hline \multicolumn{3}{|l|}{ Age } \\
\hline Mean & 41.64 & 43.14 \\
\hline Standard deviation & 12.52 & 13.43 \\
\hline Range & $22-73$ & $18-77$ \\
\hline \multicolumn{3}{|l|}{ Gender } \\
\hline Female & $57 \%$ & $59 \%$ \\
\hline \multicolumn{3}{|l|}{ Education } \\
\hline High school or below & $2 \%$ & $9 \%$ \\
\hline Associate's & $10 \%$ & $8 \%$ \\
\hline Bachelor's & $32 \%$ & $42 \%$ \\
\hline Master's and above & $50 \%$ & $36 \%$ \\
\hline Professional & $6 \%$ & $5 \%$ \\
\hline \multicolumn{3}{|l|}{ Former college athlete? } \\
\hline Yes & $17 \%$ & $16 \%$ \\
\hline \multicolumn{3}{|l|}{ Income } \\
\hline Less than $\$ 50,000$ & $13 \%$ & $20 \%$ \\
\hline$\$ 50,000$ to $\$ 99,999$ & $54 \%$ & $48 \%$ \\
\hline$\$ 100,000$ to $\$ 149,999$ & $18 \%$ & $21 \%$ \\
\hline$\$ 150,000$ to $\$ 199,999$ & $7 \%$ & $5 \%$ \\
\hline$\$ 200,000$ or more & $8 \%$ & $6 \%$ \\
\hline \multicolumn{3}{|l|}{ Ethnicity } \\
\hline Asian/Pacific Islander & $6 \%$ & $7 \%$ \\
\hline Black/African American & $9 \%$ & $8 \%$ \\
\hline Caucasian & $74 \%$ & $77 \%$ \\
\hline Hispanic & $4 \%$ & $3 \%$ \\
\hline Multiracial & $4 \%$ & $2 \%$ \\
\hline Would rather not say & $3 \%$ & $3 \%$ \\
\hline \multicolumn{3}{|l|}{ Level of sports fan?* } \\
\hline Mean (SD) & $3.45(1.15)$ & $3.87(1.11)$ \\
\hline
\end{tabular}

*Measured on a 7-point Likert-type scale from strongly disagree (1) to strongly agree (7).

costs of their choices. Therefore, your opinions and thoughts are extremely valuable.

Potential respondents were also incentivized through a random drawing of one iPad Mini 4 (Apple, Cupertino, CA). Data collection occurred during the month of May 2017. After clicking on the link, respondents were asked if they had previous hiring experience. If a respondent answered "no", they were thanked for their interest, but removed from the sample. Next, the respondents with hiring 
experience were asked to consider the following hypothetical scenario: "You are on a search committee for an open position at Capital Bank Credit Card Company. You are charged with assessing the two finalists and recommending one for an interview. Do you feel that you can handle this task?" Once again, if the respondent answered "no," they were thanked and removed from the online survey software. The scenarios were adapted from the work of Cole, Rubin, Feild, and Giles (2007), where recruiters were asked to assess résumés in a hypothetical hiring experience. The current study's scenarios were developed by the research team, tested by a panel of sport management faculty, and piloted with a small number of hiring professionals before application to the larger sample.

If a respondent passed both screening questions, the individual was randomly placed within one of the four experiments through block randomization. Table 2 displays the different experiments. The study utilized a within-subjects experimental design as prescribed Charness, Gneezy, and Kuhn (2012), where each participant assessed a control résumé (nonathlete) and a test résumé (athlete). Men's and women's soccer at the Division I level were used as the intercollegiate sports under investigation. Soccer was chosen for a number of reasons. First, given the context of Division I athletics and the location of survey respondents, only 10 sports were available to make the experiment as realistic as possible. Second, the comparison of female and male athletes limited the selection further, as five sports did not have both a male and female team. Third, the media coverage differences between men's basketball and women's basketball were too great that comparing these athletes would likely add an additional extraneous variable (revenue/nonrevenue) to the experiment. The resulting four sports included tennis, track and field, cross country, and soccer. Soccer was selected from this group because it did not include an individual sport component. Similar to avoiding the revenue/ nonrevenue aspect, differences related to individual and team sport participation were avoided as it could have had yet another extraneous variable.

With the exception of athlete status, direct internship, and gender differences, the résumés were nearly identical. Applicants had similar degrees and grade point averages from the same university; the applicants were also the same age, and had similar volunteer experiences. Both résumés met all of the required qualifications of the job description under investigation. Respondents were asked to rate each résumé on four unobserved attributes guided by signaling theory, and then provide

\section{Table 2 Experiments}

\begin{tabular}{|c|c|c|}
\hline & Control & Test \\
\hline Experiment 1 & $\begin{array}{l}\text { Male with direct internship } \\
\text { experience (Jonathan) }\end{array}$ & $\begin{array}{l}\text { Male athlete without internship } \\
\text { experience (Marcus) }\end{array}$ \\
\hline Experiment 2 & $\begin{array}{l}\text { Male with direct internship } \\
\text { experience (Jonathan) }\end{array}$ & $\begin{array}{l}\text { Female athlete without internship } \\
\text { experience (Jessica) }\end{array}$ \\
\hline Experiment 3 & $\begin{array}{l}\text { Male with direct internship } \\
\text { experience (Jonathan) }\end{array}$ & $\begin{array}{l}\text { Male athlete with direct internship } \\
\text { experience (Phil) }\end{array}$ \\
\hline Experiment 4 & $\begin{array}{l}\text { Male with direct internship } \\
\text { experience (Jonathan) }\end{array}$ & $\begin{array}{l}\text { Female athlete with direct } \\
\text { internship experience (Taylor) }\end{array}$ \\
\hline
\end{tabular}


a recommendation for an in-person interview. Following the recommendation, respondents were asked why they rated the individuals as they did. An open-ended response box was provided to collect qualitative data.

\section{Materials and Analyses}

The scaled items utilized within the current study were developed and validated previously within résumé evaluation contexts. In particular, the characteristics of leadership, intelligence, motivation, and interpersonal skills were utilized as unobserved attributes in Wilkin and Connelly's (2012) assessment of volunteer experience. As previously applied, these items were measured on a 5-point Likerttype rating scale from Very Poor (1) to Excellent (5). The recommendation item was also measured on a 5-point Likert-type scale from Definitely Not (1) to Definitely (5). This item was also utilized previously by Wilkin and Connelly (2012). Respondents were also asked whether or not they were former college athletes and to what extent they were sports fans. The former college athlete question was binary (yes or no). The sports fan item was measured on a 7-point Likert-type scale from Not at all (1) to Extremely (7). The following standard demographic questions were also included within the online questionnaire: age, gender, income, education, and ethnicity.

To answer the research questions and hypotheses, two, two-way mixeddesign analyses of covariance (ANCOVA) were conducted with follow-up multiple comparison tests and tests of simple effects. One two-way mixed-design ANCOVA was run on experiments 1 and 2, and one was run on experiments 3 and 4. The dependent variables included the respondent ratings of the four unobserved attributes and the recommendation for an interview. The within-subject variables were the ratings differences between attributes and differences between the control and test résumés. The between-subjects variable was difference in experiment (gender of the athlete). The covariate was whether a participant was or was not a former college athlete, as best methodological practice suggests it is important to control for this confounding variable (Tabachnick \& Fidell, 2012).

The main effect test of the within-subjects factor in a two-way mixed-design ANCOVA procedure can only determine if there were significant differences on the within-subject variable. Multiple comparison tests were necessary to determine which within-subjects group means differed significantly from others (RQ2 and hypotheses 1-8). According to Klockars and Sax (1986), a multiple comparison analysis is a common procedure for ANOVAs. Thus, two paired $t$ test analyses with an alpha level set at .05 were conducted to determine which attributes and recommendations differed from each other based on the mean ratings provided by participants.

To specifically answer hypotheses 9-10, the between-subjects effect of the two mixed-design ANCOVAs were analyzed to determine if differences existed in the ratings provided by participants based on the gender of the athlete. Once again, the mixed-design ANCOVA only provides information that there was a significant between-subjects effect. Two tests of simple effects were conducted to determine which between-subjects differences existed (Meyers, Gamst, \& Guarino, 2006). A test of simple effects focuses on the cell means separately for each level of a 
single independent variable, and was used similarly by Shapiro, Dwyer, and Drayer's (2016) examination of ticket price fairness. Thus, differences were sought between male and female athletes with respect to the unobserved attribute résumé ratings and interview recommendation scores.

The qualitative data were analyzed via deductive and axial coding (Saldaña, 2015). Respondents who provided open-ended responses were grouped a priori based on the recommendation difference scores. Three groups were created: those who recommended the nonathlete applicant for an interview, those who recommended the athlete applicant, and those who recommended the two applicants equally. Once grouped, the process of uncovering themes, which were determined a priori, for the unobserved attributes of leadership, intelligence, motivation, and interpersonal skills to explain why a recommendation was made occurred.

\section{Results}

A total of 311 individuals began the online survey (30\% response rate). The screening questions eliminated 74 individuals (72 for the first screening question; two for the second). In total, 235 individuals fully completed the survey, as two other respondents failed to complete the required questions. Table 1 provides the demographic information for the sample. In general, the average respondent was a middle-aged, middle-class Caucasian woman who was highly educated. Only $17 \%$ of the sample indicated that they were a college athlete, and, on a 7-point scale, the sample mean for levels of sports fan was below average (3.45).

The results of the first two-way mixed-design ANCOVA for hypotheses 1-4 indicated a significant main effect for the unobserved attributes and recommendations $(F[9,104]=12.033, p<.001$, partial eta-squared $=.51)$. The paired $t$ test procedure (results shown in Table 3) was then implemented to make pairwise comparisons. Based on these results, hypothesis 1 was partially confirmed as no

\section{Table 3 Pairwise Comparison Results (Hypotheses 1-4 and Research Question 2)}

\begin{tabular}{|c|c|c|c|c|c|c|}
\hline \multirow[b]{2}{*}{ Attribute $^{1}$} & \multicolumn{3}{|c|}{ Experiment $1(N=61)$} & \multicolumn{3}{|c|}{ Experiment $2(N=58)$} \\
\hline & $\begin{array}{l}\text { Male With } \\
\text { Internship }\end{array}$ & $\begin{array}{c}\text { Male } \\
\text { Athlete, No } \\
\text { Internship }\end{array}$ & $p$ & $\begin{array}{l}\text { Male With } \\
\text { Internship }\end{array}$ & $\begin{array}{c}\text { Female } \\
\text { Athlete, No } \\
\text { Internship }\end{array}$ & $p$ \\
\hline Leadership & 3.24 & $3.79^{\mathrm{c}}$ & $<.001$ & 3.41 & $3.33^{\mathrm{c}, \mathrm{d}}$ & .520 \\
\hline Intelligence & 3.82 & $3.89^{c}$ & .350 & 3.50 & $3.48^{\mathrm{c}}$ & .735 \\
\hline Motivation & 3.86 & $4.36^{\mathrm{a}, \mathrm{b}, \mathrm{d}}$ & $<.001$ & 3.79 & $4.03^{\mathrm{a}, \mathrm{b}}$ & .019 \\
\hline Interpersonal skills & 3.83 & $3.94^{\mathrm{c}}$ & .159 & 3.75 & $3.69^{\mathrm{a}, \mathrm{c}}$ & .878 \\
\hline Recommend $^{2}$ & 3.75 & 4.13 & .043 & 4.11 & 3.87 & .497 \\
\hline
\end{tabular}

Notes. ${ }^{1}$ Measured on a 5-point Likert-type scale from Very Poor (1) to Excellent (5). ${ }^{2}$ Measured on a 5-point Likert-type scale from Definitely Not (1) to Definitely (5). Paired $t$-test results of unobserved attributes: ${ }^{\text {a different }}$ $(p<.05)$ from leadership mean; ${ }^{b}$ different $(p<.05)$ from intelligence mean; ${ }^{c}$ different $(p<.05)$ from motivation mean; ${ }^{\mathrm{d}}$ different $(p<.05)$ from interpersonal skills mean. 
differences were found between intelligence and interpersonal skills, but statistically significant differences were found between leadership and motivation, which favored the male athlete without internship experience. Hypothesis 2 was rejected, as the male athlete received a significantly higher recommendation score than the male nonathlete with direct internship experience.

Participants of the study acknowledged that even though Marcus (athlete résumé) did not have direct internship experience, he was still sought as being a qualified applicant for the intended position. One respondent stated: "To have maintained the same GPA as Jonathan while also participating in a collegiate-level sport speaks to commitment to a goal, being self-motivated, and having really good time-management skills."

Similar to hypothesis 1 , hypothesis 3 was partially confirmed as no differences were found between leadership, intelligence, and interpersonal skills, but statistically significant differences were found between motivation, which favored the female athlete without internship experience. Hypothesis 4 was confirmed, as no statistical difference was found between the female athlete and the male nonathlete with direct internship experience as it relates to the interview recommendation.

These results provide evidence that both athletic and internship experience is sought after. The qualitative data confirmed this phenomenon. On one hand, respondents acknowledged the importance of direct internship experience of the nonathlete (Jonathan): "The relevant internship was a major factor in rating one candidate over the other. While sports are certainly a worthwhile activity, Jonathan's combination of community service and relevant professional activities made him the clear choice to offer the first interview." On the other hand, participants also touched on why the attribute of motivation may have been rated significantly higher for the athletes. "Although she (Jessica) did not have the business experience that Jonathan indicated on his résumé, Jessica comes across as a high achiever, one who balances commitments well, and a motivational leader. One can always learn a function-it's difficult to learn work ethic." Taken together, athletic experience appears to at least equal direct internship experience within this hiring scenario. Statistically significant differences were not found between every attribute and recommendation, but the athletes were perceived as more motivated and the male athlete was perceived to have more leadership skills and was more highly recommended than the individual with direct internship experience.

The results of the second two-way mixed-design ANCOVA for hypotheses 5-8 indicated a significant main effect for the unobserved attributes and recommendations $(F[9,105]=16.229, p<.001$, partial eta-squared $=.58)$. The paired $t$ test procedure was implemented to make pairwise comparisons (Table 4). As for hypothesis 5 , it was partially confirmed as the male athlete score significantly higher than the nonathlete applicant on leadership, motivation, and interpersonal skills, but no difference was found on intelligence. Hypothesis 6 was confirmed, however, the male athlete with internship experience received a statistically higher recommendation score. Qualitative data helped further describe why Phil James (male athlete) may have been rated higher on three of the four attributes and recommended for the position, "Both were well qualified, but I feel Mr. James has more experience in working with others, and is more self-motivated." Participant open-ended qualitative responses reiterated the intelligence findings. "They had 


\section{Table 4 Pairwise Comparison Results (Hypotheses 5-4 and Research Question 2)}

\begin{tabular}{|c|c|c|c|c|c|c|}
\hline \multirow[b]{2}{*}{ Attribute $^{1}$} & \multicolumn{3}{|c|}{ Experiment $3(N=57)$} & \multicolumn{3}{|c|}{ Experiment $4(N=59)$} \\
\hline & $\begin{array}{l}\text { Male With } \\
\text { Internship }\end{array}$ & $\begin{array}{c}\text { Male } \\
\text { Athlete, With } \\
\text { Internship }\end{array}$ & $p$ & $\begin{array}{l}\text { Male With } \\
\text { Internship }\end{array}$ & $\begin{array}{c}\text { Female } \\
\text { Athlete, With } \\
\text { Internship }\end{array}$ & $p$ \\
\hline Leadership & 3.32 & $3.85^{\mathrm{c}}$ & $<.001$ & 3.30 & $3.89^{c}$ & $<.001$ \\
\hline Intelligence & 3.79 & $3.81^{\mathrm{c}}$ & .821 & 3.71 & $3.74^{\mathrm{c}, \mathrm{d}}$ & .829 \\
\hline Motivation & 3.83 & $4.29^{\mathrm{a}, \mathrm{b}, \mathrm{d}}$ & $<.001$ & 3.70 & $4.26^{\mathrm{a}, \mathrm{b}, \mathrm{d}}$ & $<.001$ \\
\hline Interpersonal skills & 3.82 & $4.03^{c}$ & .027 & 3.70 & $4.01^{\mathrm{b}, \mathrm{c}}$ & .002 \\
\hline Recommend $^{2}$ & 4.03 & 4.32 & $<.001$ & 3.95 & 4.36 & $<.001$ \\
\hline
\end{tabular}

Notes. ${ }^{1}$ Measured on a 5-point Likert-type scale from Very Poor (1) to Excellent (5). ${ }^{2}$ Measured on a 5-point Likert-type scale from Definitely Not (1) to Definitely (5). Paired $t$-test results of unobserved attributes: ${ }^{\text {a different }}$ $(p<.05)$ from leadership mean; ${ }^{b}$ different $(p<.05)$ from intelligence mean; ${ }^{c}$ different $(p<.05)$ from motivationmean; ${ }^{\mathrm{d}}$ different $(p<.05)$ from interpersonal skills mean.

similar GPA and similar coursework, all of which seemed relevant to the posted position. I think both would be worth of an initial screening/interview."

Hypothesis 7 was partially confirmed, as the results were similar to hypothesis 5. The female athlete with direct internship experience scored significantly higher on each attribute except intelligence. Hypothesis 8 was confirmed. The female athlete with internship experience received a significantly higher recommendation score than the male nonathlete with internship experience. Qualitative data helped further describe why the female athlete was rated higher on three of the four attributes and recommended for an overall interview: "In the fast paced marketing world, [Jessica] Jankins may be able to use her athletic background to our advantage." Statistically significant differences were also found between the unobserved attributes for the college athletes (RQ2), as motivation was rated significantly higher than the other three attributes for males and females. In addition, interpersonal skills was rated significantly higher than leadership (experiment 2) and intelligence (experiment 4) for female athletes only.

For hypothesis 9, the between-subjects effect for the first mixed-design ANCOVA was statistically significant $(F[1]=3.780, p=.046$, partial eta squared $=.112$ ). Figure 1 provides evidence of the follow-up test of simple effects. Statistically significant differences between genders with no direct internship experience were uncovered for each unobserved attribute and the recommendation score, as the male athlete résumé received higher scores than the female athlete résumé. As a result, the hypothesis was rejected. The between-subjects effect for the second mixed-design ANCOVA (hypothesis 10) was not statistically significant $(F[1]=.075, p=.599$, partial eta squared $=.002$, Figure 2$)$. Thus, this hypothesis was confirmed, as no statistically significant differences on the attributes or the recommendation were found between the male and female former athletes with direct internship experience. As no experiment was devised to compare male and female athletes directly, no qualitative data was available for these hypotheses. 


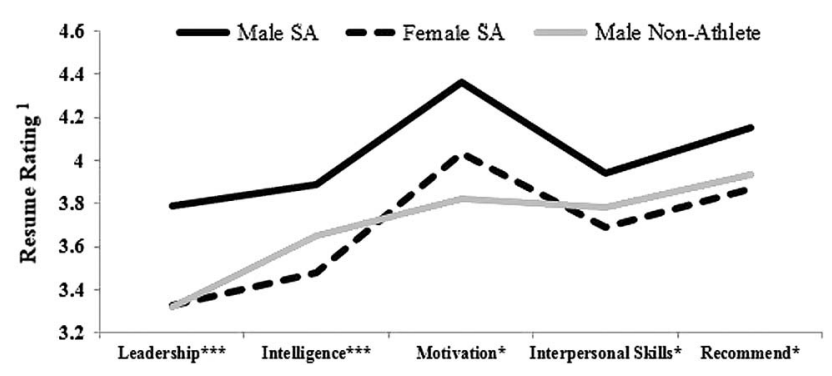

Figure 1 - Test of simple effects results for hypothesis 9 (college athletes without direct internship experience). $\mathrm{SA}=$ Student-Athlete. $* * * p<.001, * p<.05 .{ }^{1}$ Measured on 5-point Likert-type scale.

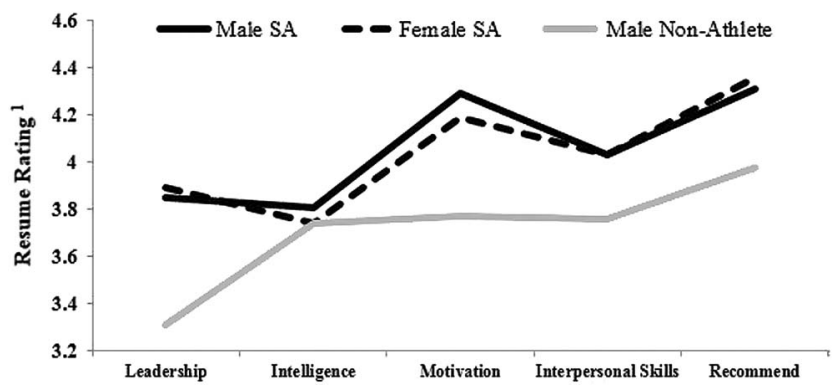

Figure 2 - Test of simple effects results for hypothesis 10 (college athletes with direct internship experience). SA $=$ Student-Athlete. ${ }^{1}$ Measured on 5-point Likert-type scale.

\section{Discussion}

The purpose of the current study was to examine the value of Division I intercollegiate athletic experience compared to and in addition to direct internship experience from four different résumé evaluation experiments. Additionally, the study examined the differences of the unobserved attributes of leadership, interpersonal skills, intelligence, and motivation while also examining the differences between male and female athlete résumés. Findings from this study make a theoretical contribution with signaling theory and have practical implications for Division I college athletic departments, athletes, and university personnel.

Experiment 1 examined attributes of a male with direct internship experience and a male with intercollegiate athletic experience and no direct internship experience. Highlighting the findings of research question 1, results suggest that even without direct job-related experience, certain attributes (leadership, intelligence, and interpersonal skills) are valued and inferred more positively for a male athlete in comparison to a male with direct internship experience. Significant findings were found in the male athlete being rated higher on attributes of leadership and motivation while also receiving an overall recommendation for an interview. Qualitative data reinforced these findings by some participants. 
One participant stated, "I'm familiar with what playing a sport at the college level requires, the need to balance class demands and team demands. It also develops leadership and interpersonal skills." Research has found negative stereotypes to be associated with male college athletes (Lawrence, Harrison, \& Stone, 2009). While this study did not directly measure stereotypes, résumés would have primed participants with inherent biases. The current study's results demonstrate potential employers view male athletes positively. More importantly, the results suggest that Division I intercollegiate athletic experience signals important characteristics equal to or more impactful than direct internship experience. This is a potentially important finding for Division I college athletes and college administrators.

Experiment 2 examined attributes of a male nonathlete with direct internship experience and a female athlete with no direct internship experience. The only significant finding was that participants rated the female athlete higher only on the attribute of motivation. The male with direct internship experience was rated higher in all other attributes and for recommendation of receiving an interview. Since female athletes have been found to be more motivated academically in comparison to male athletes, this may also hold true in comparison to all male peers (Gayles, 2005). Even with the increase in females in the workplace and females who hold managerial positions, gender stereotypes still exist. Powell et al. (2002) found that effective managers are often perceived as having masculine characteristics such as a strong personality or being forceful and dominant. Are these perceptions possibly behind the unequal treatment? A number of studies have identified perceived differences between male and female athletes within a hiring context.

For instance, Grappendorf et al. (2008) found advantages for male athletes over female athletes applying within in the financial services industry through a mock interview evaluation. Males were recommended for higher salaries than females. In 2016, Grappendorf and Burton uncovered gender bias even among sport management faculty as it relates to perceived fit within certain sport organizations. The current study's results suggest that male and female athletes within the same sport, the same school, and same academic major are still not treated equally. When controlling for the gender of the hiring professional in experiments 1 and 2, it becomes evident that males are more preferential to males. Male hiring professionals were much more likely $(\mathrm{M}=4.275)$ to recommend the male athlete than female hiring professionals $(\mathrm{M}=3.947)$ on a 5-point scale. Yet, for experiment 2 when the athlete was female, male hiring professionals were more likely to recommend the male nonathlete $(M=4.133)$ than the female hiring professional $(\mathrm{M}=3.901)$. The other recommendations were almost equal. These findings validate the work of by Koch et al. (2015) and suggest male decision makers continue to prefer male applicants despite similar credentials.

Experiment 3 and 4 compared a male and female athlete résumé to a male nonathlete, all who had direct internship experience. The three attributes of leadership, motivation, and interpersonal skills were all rated significantly greater than the male nonathlete. Also, the male and female athletes were both recommended for receiving interviews. When comparing experiments 3 and 4 to 1 and 2 it can be concluded that having both Division I intercollegiate athletic experience and direct internship experience make a college athlete most marketable. From these results it can be assumed that hiring personnel value intercollegiate athletic 
experience, and that athletic experience does signal to unobservable attributes and positive inferences of college athlete characteristics. Qualitative data highlight these findings. A participant stated: "I believe that student-athletes have better soft skills than students who did not participate in sports. They are better team players overall and tend to have better communication/problem solving skills. They tend to persevere under tough/stressful situations."

With the number of résumés that get submitted for any entry-level job position, being able to show practical experience that demonstrates transferable skills into the workplace has been found to be one of the best ways to stand out in the applicant pool (Gault, Leach, \& Duey, 2010). Themes that arose during the analysis of qualitative data aligned with this research; in experiment 1 and 2, the college athlete was most likely not recommended for an interview by a participant due to the lack of job experience. For example, a participant stated: "Jonathan had related work experience and demonstrated leadership skills and motivation through his volunteer activities. Even though Marcus had a résumé demonstrating leadership, motivation, and an educational background in marketing, I'd rather hire someone who has some hands on experience in the field." While collegiate athletic experience proves to be valuable, having both direct internship and collegiate athletic experience made the students most marketable.

While there was no experiment that directly compared the male and female athlete résumés, differences were analyzed and provide a point of discussion for hypotheses 8 and 9 . Without direct internship experience the male athlete was rated significantly higher than the female athlete on all unobservable attributes and for an interview recommendation. While past studies have not found gender differences to play a factor among college athletes and their employability (Chalfin et al., 2015; Tanguay et al., 2012), the current study's results paint a different picture and appear to support previous research by Grappendorf et al. (2008; 2016), where male athletes are preferred to female athletes in a hiring scenario. What does this mean for Division I female athletes? For one thing, it signifies that gender bias among male decision makers remains steadfast, as the results extend the work of Koch et al. (2015). Second, it implies that Division I athletic experience is not enough for females to compete evenly in an employment setting. Fair or not fair, it appears men are given more of an advantage for competing athletically than females, especially by other men. Unfortunately for females, the bias does not end at the hiring process. Gender bias remains rampant in the workplace, especially in male-dominated industries (Powell et al., 2002). Bosak and Sczesnyy (2011) found substantial gender bias when selecting leaders within an organization. Similarly, Walker and Bopp (2010) found bias in workplace expectations, culture, and compensation. However, the results remain preliminary. At this point, only differences have been identified. Future studies should examine why this is occurring. Gender bias may be playing a role in the résumé ratings of college athletes, so a qualitative extension of the current study would add further understanding to this unique result.

\section{Practical Implications}

Athletic departments and athlete services units could benefit from the results of this study. Career development opportunities for college athletes have evolved from the 
NCAA LifeSkills initiative into a career and personal development. The structure of these career and personal development units differ greatly from school to school (Kelly \& Dixon, 2014). Since there are many new programs and staff being added to help athletes with career development, it is important that research helps guide practitioners in programming development.

Recent research has acknowledged the competitive job market facing new college graduates (Cappelli, 2014; Nunley et al., 2016). While the results of this study show that certain attributes are seen to be valuable based on athletic experience, in order to be most marketable on a résumé evaluation, it is important for athletes to understand that having both athletic and direct internship experience is important. Athletes need to openly communicate with their coaches the importance of doing an internship and plan in advance a time that works best during an academic year to complete practical hands-on experience. As a student, completion of direct internship experience has been linked to finding career-oriented employment (Callanan \& Benzing, 2004).

Student services units and practitioners working with athletes can benefit from these findings. Research has demonstrated college athletes rely heavily on their academic services staff for guidance in the area of career development (Navarro, 2015). Since résumés are one of the most frequently used mechanisms for the selection and hiring of employee personnel (Robertson \& Smith, 2001), this study can assist student-services and athletes to have a better understanding of ways to market and prepare themselves for careers after sport. Résumé workshops are a practical tool athletic departments should take advantage of to benefit college athletes in the area of career development. Since intercollegiate athletic experience is seen as valuable and proves to help athletes stand out amongst their peers, providing résumé workshops tailored specifically to athletes would be beneficial to teach students how to leverage their athletic experiences to better signal unobservable attributes.

Lastly, universities as a whole can use the results from this study to understand how to better serve this unique population. Some universities have been adding career development and transition classes that are specifically offered to athletes (Weight \& Huml, 2016). These classes are used for transitioning both in and out of the college environment and serve to help bridge the gap between college and post college success. The results from this study can add reassurance that these classes are both needed and beneficial to this population of students.

\section{Theoretical Implications}

Signaling theory was used to further examine how hiring managers are signaled unobservable attributes from experiences listed on résumés. This theory suggests that job recruiters observe an abundance of biodata on job applicants and make inferences of unobservable characteristics based on the information provided (Spence, 1973). Intelligence was the only unobservable attribute in all four experiments that employers did not associate with participating in intercollegiate athletics. An explanation for this could be that all the résumés had similar grade point averages (GPAs). Signaling theory would suggest that GPAs could be inferred as a sign of intelligence; since all were held similarly to one another, there may have not been any signaled differences alluding to intelligence 
differences among the candidates. Qualitative data gathered highlighted this point: "They had similar GPA and similar coursework, all of which seemed relevant to the posted position. I think both would be worthy of an initial screening/interview."

Research question 2 examined differences between the unobserved attributes for both college athletes. Motivation was rated significantly higher than the three other attributes for both the male and female athlete. Signaling theory could help further explain the impact of Division I athletic participation on the unobservable characteristic of motivation, which may uniquely be directly related to an individual's athletic participation. Specifically, signaling theory has potential to examine between construct differences, which has not yet been examined to the researchers' knowledge prior to this study. Perhaps signaling theory could be utilized to assess different types of motivation as well. Motivation is a multidimensional construct. From Deci and Ryan's (2000) self-determination theory to Taylor's (2007) work on difference making, profitability, and status seeking, motivation appears to be an influential attribute signaled to hiring professionals, yet this study only appears to scratch the surface.

Overall, the results from this study show Division I intercollegiate athletic experience signals the unobservable attributes of leadership, interpersonal skills, and motivation. Signaling theory helped with the explanation that the overall quality of a candidate in comparison to an individual without intercollegiate athletic experience signals positive inferences to someone in a job recruiting position. This holds valuable implications for signaling theory, which helps explain the value intercollegiate athletics can have on an individual's unobservable attributes. While Division I intercollegiate athletic experience was found to be valuable and signal certain unobservable attributes, athletes should still strive to have direct internship experience to complement their intercollegiate athletic experience, to be the most marketable. Furthermore, these results should be shared with all college students, as well-rounded attributes such as leadership, intelligence, interpersonal skills, and motivation appear to have merit among hiring professionals. Perhaps more effort should be afforded to finding other experiences at the college level that signals these attributes, and more incentive should be provided to college students to get involved in extracurricular activities as they may carry more weight in a résumé evaluation scenario.

Signaling theory also fell short in a few areas, as differences were found within experiments for likelihood to recommend, yet differences were not found between unobservable attributes. In other words, unobservable attributes may not be telling the entire story. Something else might be at play that signals a hiring professional or signaling may not be involved. It could be as simple as gender bias within an individual or another subconscious bias that would lead a hiring professional to select one person over the other. In addition, sport participation may have an unfair advantage over direct internship experience. In our society, sport is seen as a proven means for character development. Shields and Bredemeier (2005) highlighted our culture's fascination with sport as a character builder despite little evidence of its efficacy. Thus, the current study examined broad attributes that likely benefited athletic experience over direct internship experience. Most of the work in signaling theory and hiring practices focus on broad attributes such as intelligence, leadership, motivation, and interpersonal skills. Future work should include more specific attributes toward a job or industry. If the current study had 
assessed sales skills or attributes directly related to working with clients, perhaps the nonathlete would have faired differently.

\section{Limitations and Future Research}

This study was not without limitations. First, it tested professionals with direct hiring experience, but did not assess professionals solely within the industry under examination. In other words, the open position was for a made-up company similar to a Fortune 500 company in the area, but not everyone who participated had experience with marketing, finance, or customer service. Second, men's and women's soccer at the Division I level were the only sports and level tested. There is certainly an opportunity to explore the potential influence of other sports. For instance, how do perceptions change based on revenue sports compared to nonrevenue sports? Does the level of competition matter for hiring professionals? Lastly, because of constraints related to time on task, only one control résumé was used. This control résumé was a male, and thus, there was no comparison for a female nonathlete against the test résumés.

Future studies should continue to examine the value of intercollegiate athletics and the benefits gained from being an athlete for life after sport. Since many college athletes will not play their sport professionally after they have exhausted their college athletic eligibility, it is crucial to find out more about how athletic experience can be leveraged to help athletes succeed upon entering the workforce. Future research should also continue to explore the gender biases between males and females who are entering the workforce. The discrepancy between the male and female athlete ratings in experiment 1 and 2 warrants further investigation.

\section{References}

Abraham, M. (2017). Pay formalization revisited: Considering the effects of manager gender and discretion on closing the gender wage gap. Academy of Management Journal, 60, 29-54. doi:10.5465/amj.2013.1060

Aldas, T., Crispo, V., Johnson, N., \& Price, T.A. (2010). Learning by doing: The Wagner plan from classroom to career. Peer Review, 12(4), 24.

Astin, W. (1984). Student involvement: A developmental theory for higher education. Journal of college student personnel, 25, 297-308.

Bangerter, A., \& Roulin, N. (2012). Personnel selection as a signaling game. Journal of Applied Psychology, 97, 719-738. PubMed. doi:10.1037/a0026078

Bastie, F. (2015, October 2). Recruiting column: Employers want to hire college athletes. USA Today. Retrieved from http://usatodayhss.com/2015/recruiting-columnemployers-want-to-hire-college-athletes

Bok, D. (2003). Universities in the marketplace: The commercialization of higher education. Princeton, NJ: Princeton University Press.

Bosak, J., \& Sczesny, S. (2011). Gender bias in leader selection? Evidence from a hiring simulation study. Sex Roles, 65, 234-242. doi:10.1007/s11199-011-0012-7

Briggeman, B.C., \& Norwood, B.F. (2011). Employer assessment of the college graduate: What advisors need to know. Journal of Natural Resources \& Life Sciences Education, 40, 19-28. doi:10.4195/jnrlse.2009.0040 
Bureau of Labor Statistics. (2017). Labor force statistics from the current population survey. Retrieved from https://www.bls.gov/cps/

Callanan, G., \& Benzing, C. (2004). Assessing the role of internships in the career-oriented employment of graduating college students. Education \& Training, 46, 82-89. doi: $10.1108 / 00400910410525261$

Cantor, J.A. (1997). Experiential learning in higher education: Linking classroom and community. ERIC Digest. Retrieved from https://www.ericdigests.org/1997-4/higher.htm

Cappelli, P. (2014). Skill gaps, skill shortages and skill mismatches: Evidence for the US. National Bureau of Economic Research.

Carlsson, R., \& Sinclair, S. (2018). Prototypes and same-gender bias in perceptions of hiring discrimination. The Journal of Social Psychology, 158(3), 285-297. doi:10.1080/ 00224545.2017.1341374

Chalfin, P., Weight, E., Osborne, B., \& Johnson, S. (2015). The value of intercollegiate athletics participation from the perspective of employers who target athletes. Journal of Issues in Intercollegiate Athletics, 8, 1-27.

Charness, G., Gneezy, U., \& Kuhn, M.A. (2012). Experimental methods: Between-subject and within-subject design. Journal of Economic Behavior \& Organization, 81, 1-8. doi:10.1016/j.jebo.2011.08.009

Coach for College. (2017). Challenges facing student-athletes. Infosheet. Retrieved from www.coachforcollege.org/Assets/Infosheets/Challengesfacingstudent-athletes.pdf

Cole, M.S., Rubin, R.S., Feild, H.S., \& Giles, W.F. (2007). Recruiters' perceptions and use of applicant résumé information: Screening the recent graduate. Applied Psychology, 56, 319-343. doi:10.1111/j.1464-0597.2007.00288.x

Connelly, B.L., Certo, S.T., Ireland, R.D., \& Reutzel, C.R. (2011). Signaling theory: A review and assessment. Journal of Management, 37, 39-67. doi:10.1177/01492063 10388419

Creswell, J.W., \& Plano Clark, V.L. (2011). Designing and conducting mixed methods research (2nd ed.). Thousand Oaks, CA: Sage.

Creswell, J.W., Plano Clark, V.L., Gutmann, M.L., \& Hanson, W.E. (2003). Advanced mixed methods research designs. In A. Tashakkori\& C. Teddlie (Eds.), Handbook of mixed methods in social and behavioral research (pp. 209-240). Thousand Oaks, CA: Sage.

Eagly, A.H., \& Karau, S.J. (2002). Role congruity theory of prejudice toward female leaders. Psychological Review, 109, 573-598.

Deci, E.L., \& Ryan, R.M. (2000). The "what" and "why" of goal pursuits: Human needs and the self-determination of behavior. Psychological Inquiry, 11(4), 227-268.

Gault, J., Leach, E., \& Duey, M. (2010). Effects of business internships on job marketability: The employers' perspective. Education \& Training, 52, 76-88. doi:10.1108/ 00400911011017690

Gault, J., Redington, J., \& Schlager, T. (2000). Undergraduate business internships and career success: Are they related? Journal of Marketing Education, 22, 45-53. doi:10. $1177 / 0273475300221006$

Gayles, J.G. (2005). The factor structure and reliability of the student athletes' motivation toward sports and academic questionnaire (SAMSAQ). Journal of College Student Development, 46(3), 317-327. doi:10.1353/csd.2005.0025

Gayles, J.G., \& Hu, S. (2009). The influence of student engagement and sport participation on college outcomes among division I student athletes. The Journal of Higher Education, 80, 315-333. doi:10.1080/00221546.2009.11779015

Grappendorf, H., \& Burton, L.J. (2014). Examining the influence of athletic participation in evaluation of entry-level positions in financial services: An application of role congruity theory. Journal for the Study of Sport and Athletes in Education, 8, 19-32. doi:10.1179/1935739714Z.00000000016 
Grappendorf, H., \& Burton, L.J. (2016). Are sport management faculty biased? An examination of faculty perceptions of male and female students' applications for a job in sport. Global Sports Business Journal, 4(3), 1-10.

Grappendorf, H., Burton, L.J., \& Henderson, A.C. (2008). Do athletes have an advantage in initial salary recommendations? A role conguity theory examine initial salary recommendations. Applied Research in Coaching and Athletics Manual, 23, 147.

Harvey-Cook, J.E., \& Taffler, R.J. (2010). Biodata in professional entry level selection: Statistical scoring of common format applications. Journal of Occupational and Organizational Psychology, 73, 103-118. doi:10.1348/096317900166903

Haslerig, S.J., \& Navarro, K.M. (2015). Aligning athletes' career choices and graduate degree pathways. Journal of Career Development, 43, 211-226. doi:10.1177/0894845315597472

Holmes, P. (2011). Win or go home: Why college football coaches get fired. Journal of Sports Economics, 12, 157-178. doi:10.1177/1527002510378820

Howard-Hamilton, M.F., \& Watt, S.K. (2001). Student services for athletes (New directions for student services no. 93). San Francisco, CA: Jossey-Bass.

Huma, R., \& Staurowsky, E.J. (2011, September). The price of poverty in big-time college sports. Riverside, CA: National College Players Association.

Kelly, D.D., \& Dixon, M.A. (2014). Successfully navigating life transitions among African American male student-athletes: A review examination of constellation mentoring as a promising strategy. Journal of Sport Management, 28, 498-514. doi:10.1123/jsm. 2012-0320

Klockars, A.J., \& Sax, G. (1986). Multiple comparisons. Thousand Oaks, CA: Sage Publications.

Koch, A.J., D'Mello, S.D., \& Sackett, P.R. (2015). A meta-analysis of gender stereotypes and bias in experimental simulations of employment decision making. Journal of Applied Psychology, 100, 128-161. PubMed. doi:10.1037/a0036734

Lavalle, J.J. (2010). What motivates OCB? Insights from the volunteerism literature. Journal of Organizational Behavior, 31, 918-923. doi:10.1002/job.644

Lawrence, S.M., Harrison, C.K., \& Stone, J. (2009). A day in the life of a male college athlete: A public perception and qualitative campus investigation. Journal of Sport Management, 23, 591-614. doi:10.1123/jsm.23.5.591

Maurath, D.T., Wright, C.W., Wittorp, D.E., \& Hardtke, D. (2015). Volunteer experiences may not bridge the gap in employment. International Journal of Selection and Assessment, 23, 284-294. doi:10.1111/ijsa.12114

Meyers, L.S., Gamst, G., \& Guarino, A.J. (2006). Applied multivariate research. Thousand Oaks, CA: Sage.

Miller, P.S., \& Kerr, G. (2002). The athletic, academic and social experiences of intercollegiate student-athletes. Journal of Sport Behavior, 25, 346-360.

National Collegiate Athletic Association. (2011). NCAA student-athletes [Television Commercial]. Retrieved from https://www.youtube.com/watch?v=9UzO4DJBoWw

National Collegiate Athletic Association. (2016a) NCAA GOALS study of the studentAthlete experience: Initial summary of findings. Retrieved from http://www.ncaa.org/ sites/default/files/GOALS_2015_summary_jan2016_final_20160627.pdf

National Collegiate Athletic Association. (2016b). Trends in graduation success rate and federal graduation rates at NCAA division I institutions. Retrieved from http://www. ncaa.org/sites/default/files/2016RES_GSRandFedTrends-Final_sc_20161114.pdf

Navarro, K.M. (2015). An examination of the alignment of student-athletes' undergraduate major choices and career aspirations in life after sport. Journal of College Student Development, 56, 364-379. doi:10.1353/csd.2015.0034

Nemanick, R.C., \& Clark, E.M. (2002). The differential effects of extracurricular activities on attributions in résumé evaluation. International Journal of Selection and Assessment, 10, 206-217. doi:10.1111/1468-2389.00210 
Nunley, J.M., Pugh, A., Romero, N., \& Seals, R.A. (2016). College major, internship experience, and employment opportunities: Estimates from a résumé audit. Labour Economics, 38, 37-46. doi:10.1016/j.labeco.2015.11.002

Papacharisis, V.P., Goudas, M., Danish, S.J., \& Theodorakis, Y. (2005). The effectiveness of teaching a life skills program in a spot context. Journal of Applied Sport Psychology, 17, 247-254. doi:10.1080/10413200591010139

Pascarella, E.T., \& Terenzini, P.T. (2005). How college affects students: A third decade of research (2nd ed.). San Francisco, CA: Jossey-Bass.

Paule, A.L., \& Gilson, T.A. (2010). Current collegiate experiences of big-time, non-revenue, NCAA athletes. Journal of Intercollegiate Sport, 3, 333-347. doi:10.1123/jis.3.2.333

Potuto, J.R., \& O'Hanlon, J. (2007). National study of student-athletes regarding their experiences as college students. College Student Journal, 41, 947-967.

Powell, G.N., Butterfield, D.N., \& Parent, J.D. (2002). Gender and managerial stereotypes: Have the times changed? Journal of Management, 28, 177-193. doi:10.1177/ 014920630202800203

Robertson, I.T., \& Smith, M. (2001). Personnel selection. Journal of Occupational and Organizational Psychology, 74, 441-472. doi:10.1348/096317901167479

Rubin, L.M., \& Moses, R.A. (2017). Athletic subculture within student-athlete academic centers. Sociology of Sport Journal, 34(4), 317-328. doi:10.1123/ssj.2016-0138

Ryan, F.J. (1989). Participation in intercollegiate athletics: Affective outcomes. Journal of College Student Development, 30, 122-128.

Saldaña, J. (2015). The coding manual for qualitative researchers. Thousand Oaks, CA: Sage.

Shapiro, S.L., Dwyer, B., \& Drayer, J. (2016). Are you playing fair? Examining the role of fairness in sport consumer ticket purchase decisions. Sport Marketing Quarterly, 25, 257-263.

Shields, D.L., \& Bredemeier, B. (2005). Can sports build character. In D.K. Lapsley\& F.C. Power's (Eds.), Character psychology and character education (pp. 121-139). South Bend, IN: University of Notre Dame Press.

Southall, R.M., Southall, C., \& Dwyer, B. (2009). 2009 Bowl Championship Series telecasts: Expressions of big-time college-sport's commercial institutional logic. Journal of Issues in Intercollegiate Athletics, 2, 150-176.

Southall, R.M., \& Staurowsky, E.J. (2013). Cheering on the collegiate model: Creating, disseminating, and imbedding the NCAA's redefinition of amateurism. Journal of Sport and Social Issues, 37, 403-429. doi:10.1177/0193723513498606

Spence, M. (1973). Job market signaling. The Quarterly Journal of Economics, 87, 355-374. doi:10.2307/1882010

Sturm, J.E., Feltz, D.L., \& Gilson, T.A. (2011). A comparison of athlete and student identity for division I and division III athletes. Journal of Sport Behavior, 34, 295-306.

Tabachnick, B.G., \& Fidell, L.S. (2012). Using multivariate statistics (6th ed.). Boston, MA: Pearson Education.

Tanguay, D.M., Camp, R.R., Endres, M.L., \& Torres, E. (2012). The impact of sports participation and gender on inferences drawn from résumés. Journal of Managerial Issues, 2, 191-206.

Taylor, D.E. (2007). Diversity and equity in environmental organizations: The salience of these factors to students. The Journal of Environmental Education, 39(1), 19-44.

Umbach, P.D., Palmer, M.M., Kuh, G.D., \& Hannah, S.J. (2006). Intercollegiate athletes and effective educational practices: Winning combination or losing effort? Research in Higher Education, 47, 709-733. doi:10.1007/s11162-006-9012-9

Walker, N.A., \& Bopp, T. (2010). The underrepresentation of women in the male-dominated sport workplace: Perspectives of female coaches. Journal of Workplace Rights, 15, 47-64. doi:10.2190/WR.15.1.d 
Watt, S.K., \& Moore, J.L. (2001). Student services for athletes (New directions for student services no. 93). San Francisco, CA: Jossey-Bass.

Weight, E.A., \& Huml, M.R. (2016). Education through athletics: An examination of academic courses designed for NCAA athletes. Journal of Intercollegiate Sport, 9, 352-378. doi:10.1123/jis.2015-0051

Weight, E., Navarro, K., Huffman, L., \& Smith-Ryan, A. (2014). Quantifying the psychological benefits of intercollegiate athletics participation. Journal of Issues in Intercollegiate Athletics, 7, 309-409.

Wilkin, C.L., \& Connelly, C.E. (2012). Do I look like someone who cares? Recruiters' ratings of applicants' paid and volunteer experience. International Journal of Selection and Assessment, 20, 308-318. doi:10.1111/j.1468-2389.2012.00602.x 